\title{
Electrical conductivity and thermal behavior of solid electrolytes based on alkali carbonates and sulfates
}

\author{
S. Brosda ${ }^{a} *$, H.J.M. Bouwmeester ${ }^{b}$, U. Guth ${ }^{a}$ \\ ${ }^{a}$ Institute of Physical Chemistry, University of Greifswald, Greifswald, Germany \\ ${ }^{b}$ University of Twente, Enschede, The Netherlands
}

\begin{abstract}
Both thermal stability and electrical conductivity of alkali ion conducting $\mathrm{Na}_{2} \mathrm{CO}_{3}$ and $\mathrm{Na}_{2} \mathrm{SO}_{4}$, were improved by adding alkaline earth carbonates and sulfates, respectively, as well as insulating materials like $\gamma-\mathrm{Al}_{2} \mathrm{O}_{3}$. The admixing of divalent compounds causes two effects. First a more or less extended solution can exist depending on the radius of the alkaline earth ion and is accompanied by an increase in electrical conductivity. Secondly, a phase mixture with an excess of dopant was observed that shows an enhancement in conductivity and mechanical stability. This phenomenon known as composite effect was observed in the following systems: $\mathrm{Na}_{2} \mathrm{CO}_{3}-\mathrm{BaCO}_{3}, \mathrm{Na}_{2} \mathrm{CO}_{3}-\mathrm{SrCO}_{3}, \mathrm{Na}_{2} \mathrm{SO}_{4}-\mathrm{BaSO}_{4}, \mathrm{Na}_{2} \mathrm{SO}_{4}-\gamma-\mathrm{Al}_{2} \mathrm{O}_{3}$.
\end{abstract}

Keywords: Alkali carbonates; Alkali sulfates; Composite; Conductivity; Thermal stability

Materials: $\mathrm{Na}_{2} \mathrm{CO}_{3} ; \mathrm{BaCO}_{3} ; \mathrm{SrCO}_{3} ; \mathrm{CaCO}_{3} ; \mathrm{Na}_{2} \mathrm{SO}_{4} ; \mathrm{SrSO}_{4} ; \mathrm{CaSO}_{4} ; \mathrm{BaSO}_{4} ; \gamma-\mathrm{Al}_{2} \mathrm{O}_{3}$

\section{Introduction}

Solid sodium carbonate and sulfate are fast ionic conductors with negligible electronic conductivity at higher temperatures. They can be used as solid electrolytes in potentiometric cells for rapid determination of $\mathrm{CO}_{2}$ and $\mathrm{SO}_{x}$ [1]. The pure salts exhibit a phase transition into a high temperature phase accompanied by a change of thermal expansion coefficient so that the production of long-term thermally stable sintered layers or discs is not possible.

Therefore, much work was devoted to stabilize the high temperature phase to ambient temperature by

\footnotetext{
${ }^{*}$ Corresponding author. Tel.: +49-3834 864 426; fax: +493834864 303; e-mail: brosda@gryps1.rz.uni-greifswald.de
}

well-known methods of doping. Additionally, the electrical conductivity is enhanced. Considerable effort is being made to develop in such a way $\mathrm{Li}^{+}$-based electrolytes in respect of high energy density batteries [2].

This paper intends to compare the results obtained from two new systems with those described in previous papers in order to show the different kinds of doping and their resulting electrical effects.

\section{Experimental}

Mixtures of carbonates and sulfates ( 1 $x) \mathrm{M}_{2} \mathrm{CO}_{3}+x \mathrm{MeCO}_{3},(1-x) \mathrm{M}_{2} \mathrm{SO}_{4}+x \mathrm{MeSO}_{4}$ and $\mathrm{M}_{2} \mathrm{SO}_{4}+\gamma-\mathrm{Al}_{2} \mathrm{O}_{3}$ with $\mathrm{M}=\mathrm{K}, \mathrm{Na} ; \mathrm{Me}=\mathrm{Ca}, \mathrm{Sr}$, 
Ba were prepared in a ball mill, pressed into pellets and sintered for $15 \mathrm{~h}$ at $50 \mathrm{~K}$ below their melting temperature. The electrical conductivity measurements were carried out using the four electrode $\mathrm{dc}$ method as well as by impedance spectroscopy. The results obtained were found to be equal for both methods. The experimental details were published elsewhere [3,4]. DSC (differential scanning calorimetry) measurements were performed on pressed compact samples in the temperature range 20 $500^{\circ} \mathrm{C}$ at a heating rate of $5 \mathrm{~K} / \mathrm{min}$ using $\alpha$-alumina as a reference. The procedure of heating and cooling was carried out threefold.

For SEM/EDX investigations the equipment of Zeiss, Oberkochen, Germany was used.

\section{Results and discussion}

In the Arrhenius plots of conductivity, mostly three major regions can be distinguished with respect to their different slopes (Fig. 1). The high temperature region is determined due to formation of Frenkel defects (intrinsic disorder) according to:

$\mathrm{Na}_{\mathrm{Na}}+\mathrm{V}_{\mathrm{i}} \Leftrightarrow \mathrm{Na}_{\mathrm{i}}+\mathrm{V}_{\mathrm{Na}}^{\prime}$

In the medium temperature region the extrinsic disorder caused by doping with aliovalent ions or by impurities can be described by:

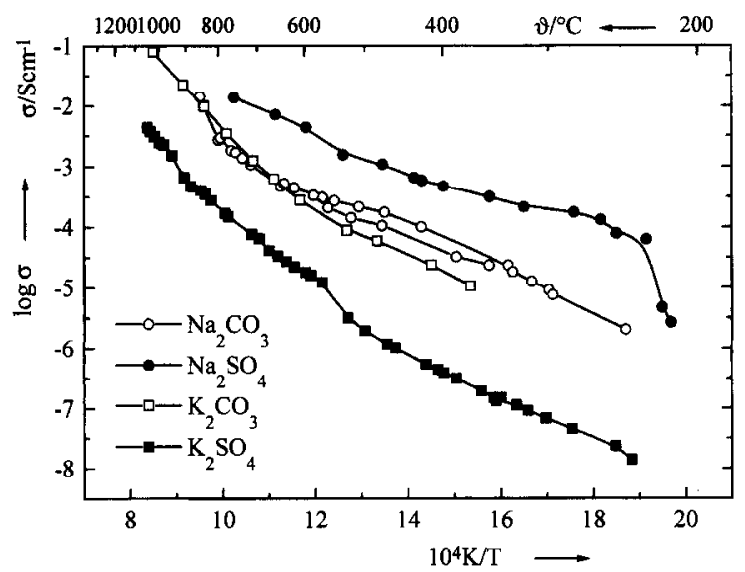

Fig. 1. Temperature dependence of conductivity of undoped alkaline carbonates and sulfates.

$$
\begin{aligned}
\mathrm{MeX} & \Leftrightarrow \mathrm{Me}_{\mathrm{Na}}^{\prime}+\mathrm{V}_{\mathrm{Na}}^{\prime}+\mathrm{X}_{x} \\
(\mathrm{X} & \left.=\mathrm{SO}_{4}^{2-}, \mathrm{CO}_{3}^{2-} ; \mathrm{Me}=\mathrm{Ca}, \mathrm{Sr}, \mathrm{Ba}\right) .
\end{aligned}
$$

The low temperature region is governed by a much lower solubility of aliovalent ions in the low temperature phase, in some cases additional by formation of clusters.

\subsection{Homogeneous doping}

The solubility of divalent ions in sodium carbonate and sulfates depends on the ionic radii of the dopants as expected and occurs to be quite different. In the case of comparable radii, about $7 \mathrm{~mol} \%$ of the dopant dissolves homogeneously. This behavior can be shown on the system $\mathrm{K}_{2} \mathrm{SO}_{4}-\mathrm{BaSO}_{4}$ [4]. This is in good agreement with results on $\mathrm{Li}_{2} \mathrm{SO}_{4}-\mathrm{CaSO}_{4}$ reported by Singh and Bhoga [5]. On the other hand, in $\mathrm{Na}_{2} \mathrm{CO}_{3}$ only less than $0.005 \mathrm{~mol} \%$ are dissolved, as can be seen in the extrinsic region represented in Fig. 2. This small amount is sufficient for preparing long-term gas-tight discs that can be used as a solid electrolyte for the determination of $\mathrm{CO}_{2}$ concentrations. Cell voltages could be measured with values according to the Nernst equation in the temperature region $380-650^{\circ} \mathrm{C}$ for 7 vol.ppm to $10 \mathrm{vol} . \%$ without cross sensitivity against water vapor [6]. It seems to be an influence of defects on the kinetics of the electrode reaction as was shown in our previous paper [7].

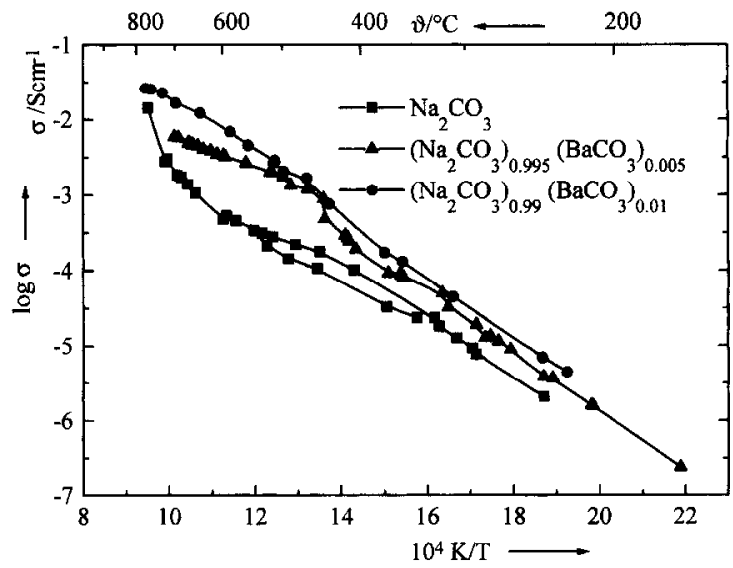

Fig. 2. Temperature dependence of conductivity of $\mathrm{BaCO}_{3}$-doped $\mathrm{Na}_{2} \mathrm{CO}_{3}$. 


\subsection{Homogeneous and heterogeneous (mixed)} doping

A phase mixture consisting of both, the homogeneous phase and the excess of dopant, is formed, by adding a dopant amount over the limit of solubility. The conductivity increases with regard to the extrinsic disorder as well as by defects formed at the phase boundary [8]

$\mathrm{Na}_{\mathrm{Na}}+\mathrm{V}_{\mathrm{A}} \Leftrightarrow \mathrm{Na}_{\mathrm{A}}^{\prime}+\mathrm{V}_{\mathrm{Na}}^{\prime}$.

A maximum in conductivity was found to occur at about $20 \mathrm{~mol} \% \mathrm{BaSO}_{4}$ as illustrated previously [4]. Although the enhancement in conductivity in these composites is not very large, it should be noted that the grain size of the dispersoid depends mainly on the preparation conditions and influences the electrical properties.

The comparison of the activation energy for $\mathrm{Na}_{2} \mathrm{CO}_{3}-\mathrm{SrCO}_{3}$ and $\mathrm{Na}_{2} \mathrm{CO}_{3}-\mathrm{BaCO}_{3}$ listed in Table 1 and shown in Fig. 3 represents both kinds of doping. In these mixtures, the mechanism in $\sigma$ enhancement appears to be similar to that in alumina dispersed solid electrolytes first described by Liang [2]. Furthermore, the conductivity behavior is influenced by formation of a new compound as could be observed in the $\mathrm{Na}_{2} \mathrm{CO}_{3}-\mathrm{SrCO}_{3}$ system with the composition $\mathrm{Na}_{2} \mathrm{Sr}_{2}\left(\mathrm{CO}_{3}\right)_{5}$ [3].

This phenomenon in mixed doped phases detected

Table 1

Comparison of $\sigma_{0}$ and activation energy $E_{\mathrm{A}}$ of doped $\mathrm{Na}_{2} \mathrm{CO}_{3}$ (in italic extrinsic region)

\begin{tabular}{llll}
\hline$x(\mathrm{~mole})$ & $\varphi\left({ }^{\circ} \mathrm{C}\right)$ & $\sigma_{0}\left(\mathrm{~S} \mathrm{~cm}^{-1}\right)$ & $E_{\mathrm{A}}\left(\mathrm{kJ} \mathrm{mol}{ }^{-1}\right)$ \\
\hline$\left(\mathrm{Na}_{2} \mathrm{CO}_{3}\right)_{1-x}\left(\mathrm{BaCO}_{3}\right)_{x}$ & this paper $]$ \\
0 & $<400$ & $57.1 \pm 4.7$ & $76 \pm 8$ \\
& $400 \ldots 600$ & $0.2 \pm 2.3$ & $45 \pm 5$ \\
& $>600$ & $(3.6 \pm 0.1) \cdot 10^{2}$ & $101 \pm 20$ \\
0.01 & $280 \ldots 700$ & $(12 \pm 3.7) 10^{3}$ & $100 \pm 8$ \\
0.03 & $300 \ldots 700$ & $2.6 \cdot 10^{2}$ & 83 \\
0.2 & $250 \ldots 600$ & $(1.0 \pm 0.01) \cdot 10^{3}$ & $88 \pm 2$ \\
0.5 & $380 \ldots 650$ & $12.5 \pm 2.1$ & $88 \pm 5$ \\
& & & \\
$\left(\mathrm{Na}_{2} \mathrm{CO}_{3}\right)_{1-x}\left(\mathrm{SrCO}_{3}\right)_{x}[3]$ & & \\
0.01 & $620 . .785$ & $6.4 \pm 0.2$ & $34 \pm 2$ \\
0.03 & & & $29.7 \pm 0.02$ \\
0.2 & $630 \ldots 680$ & $(5 \pm 3) \cdot 10^{2}$ & $68 \pm 10$ \\
0.5 & $470 . .700$ & $(18 \pm 3) \cdot 10^{3}$ & $83 \pm 2$ \\
\hline
\end{tabular}

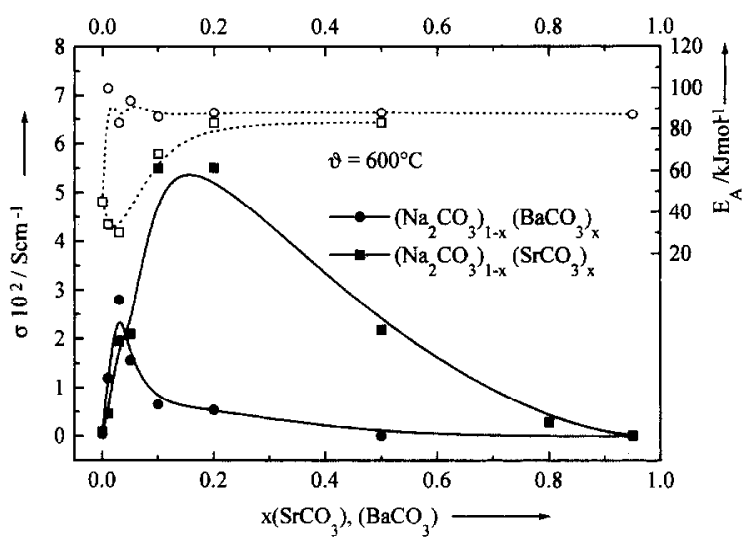

Fig. 3. Comparison of conductivities and activation energies between $\mathrm{BaCO}_{3}$ - and $\mathrm{SrCO}_{3}$-doped $\mathrm{Na}_{2} \mathrm{CO}_{3}$.

by electrical conductivity measurements could be shown semiquantitatively by SEM/EDX studics as well. In the system $\mathrm{Na}_{2} \mathrm{SO}_{4}-\mathrm{BaSO}_{4}$ it can be distinguished between crystals from a homogeneous solid solution of $\mathrm{BaSO}_{4}$ in $\mathrm{Na}_{2} \mathrm{SO}_{4}$ and a second $\mathrm{BaSO}_{4}$ phase.

The mechanism of ion transport in this material is not well understood. The 'paddle wheel' mechanism introduced by Lunden [9] and a percolation model proposed by Secco et al. [10] have been discussed for cubic $\alpha-\mathrm{Li}_{2} \mathrm{SO}_{4}$. According to our previous measurements of activation energies, e.g., for $\mathrm{K}_{2} \mathrm{SO}_{4}-\mathrm{BaSO}_{4}$ and the obtained effect of mixed doping, we found the percolation type transport mechanism [11] to be the more suitable model.

\subsection{Heterogeneous doping}

$\gamma-\mathrm{Al}_{2} \mathrm{O}_{3}$ as the most effective dispersoid was used to prepare $\mathrm{Na}_{2} \mathrm{SO}_{4}$-based composites. The conductivity $\sigma$ was enhanced by 1 to 2 orders of magnitude and its maximum was found to be at about 40 vol.\% as reported in literature [2]. Furthermore after breaking, the microstructure of composites shows wellformed sodium sulfate crystals embedded in small alumina particles (Fig. 4). By adding alumina to mixtures of $\mathrm{Na}_{2} \mathrm{SO}_{4} \quad \mathrm{BaSO}_{4}$ an enhancement in $\sigma$ occurs as compared with those which contain no alumina [4]. Such composites look like porcelain and behave very well mechanically.

Kinetics of phase transformation $\mathrm{Na}_{2} \mathrm{SO}_{4}(\mathrm{III}) \rightarrow$ 


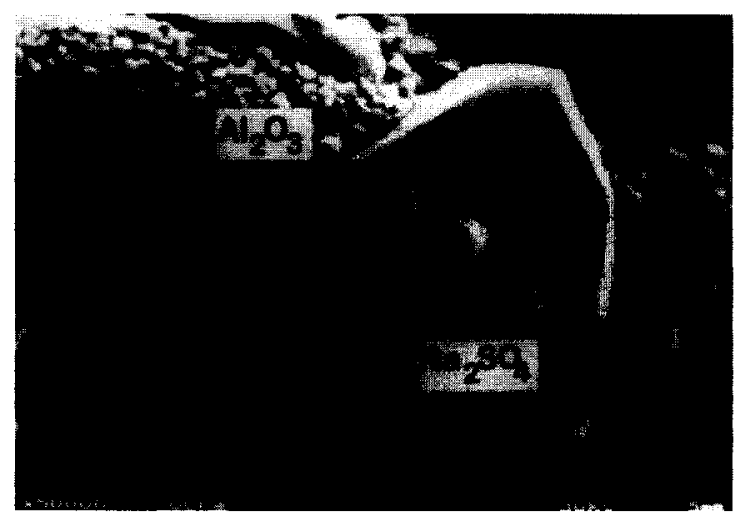

Fig. 4. SEM picture of the surfaces after breaking of a $\gamma-\mathrm{Al}_{2} \mathrm{O}_{3}$ doped $\mathrm{Na}_{2} \mathrm{SO}_{4}$ sample.

$\mathrm{Na}_{2} \mathrm{SO}_{4}(\mathrm{I})$ and vice-versa [12] were studied under dynamic conditions by DSC. For this reason, a pressed unsintered sample of $\mathrm{Na}_{2} \mathrm{SO}_{4}-\gamma-\mathrm{Al}_{2} \mathrm{O}_{3}$ $(60: 40$ vol.\%) was heated at the linear rate of 5 $\mathrm{K} / \mathrm{min}$ up to $500^{\circ} \mathrm{C}$ and cooled at the same rate. A shift in the transition temperature occurred differently during heating and cooling towards a lower temperature as compared to pure $\mathrm{Na}_{2} \mathrm{SO}_{4}$. Surprisingly, by threefold repetition of this procedure the transition heat was diminished. In the first run, an almost appropriate amount of heat was measured whereas in the second run, much less heat was determined. The sintered samples showed the same behavior during the first run. Obviously, the more composite was formed by sintering the less intense the phase transition could be observed. The phase transition seems to be restrained kinetically. The

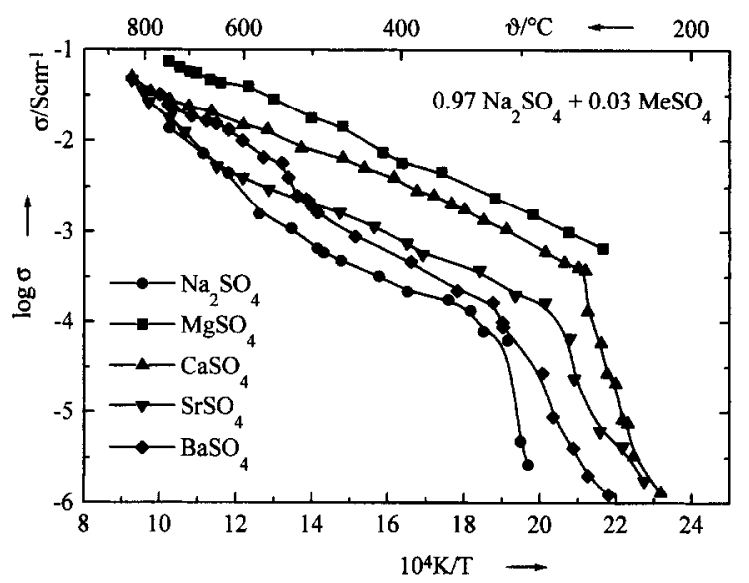

Fig. 5. Temperature dependence of conductivity of alkaline earth doped $\mathrm{Na}_{2} \mathrm{SO}_{4}$.

results of DSC measurements are collected in Table 2.

The influence of dopants on the phase transition in equilibrium or steady state is studied in Fig. 5 for $\left(\mathrm{Na}_{2} \mathrm{SO}_{4}\right)_{0.97}\left(\mathrm{MeSO}_{4}\right)_{0.03}$. The transition temperature $\left(241^{\circ} \mathrm{C}\right)$ of the $\mathrm{Na}_{2} \mathrm{SO}_{4}(\mathrm{III}) \rightarrow \mathrm{Na}_{2} \mathrm{SO}_{4}$ (I) pure phase transition was shifted to the lower value with decreasing ionic radius of $\mathrm{Me}=\mathrm{Ba}, \mathrm{Sr}, \mathrm{Ca}, \mathrm{Mg}$. The samples exhibited an excellent thermal shock resistivity.

\section{Conclusion}

In the systems $\mathrm{Na}_{2} \mathrm{CO}_{3}-\mathrm{MeCO}_{3}, \mathrm{Na}_{2} \mathrm{SO}_{4}-\mathrm{BaSO}_{4}$ and $\mathrm{Na}_{2} \mathrm{SO}_{4}-\gamma-\mathrm{Al}_{2} \mathrm{O}_{3}$ three main types of doping

Table 2

Results of DSC measurements obtained on different $\mathrm{Na}_{2} \mathrm{SO}_{4}-\gamma-\mathrm{Al}_{2} \mathrm{O}_{3}$ composition

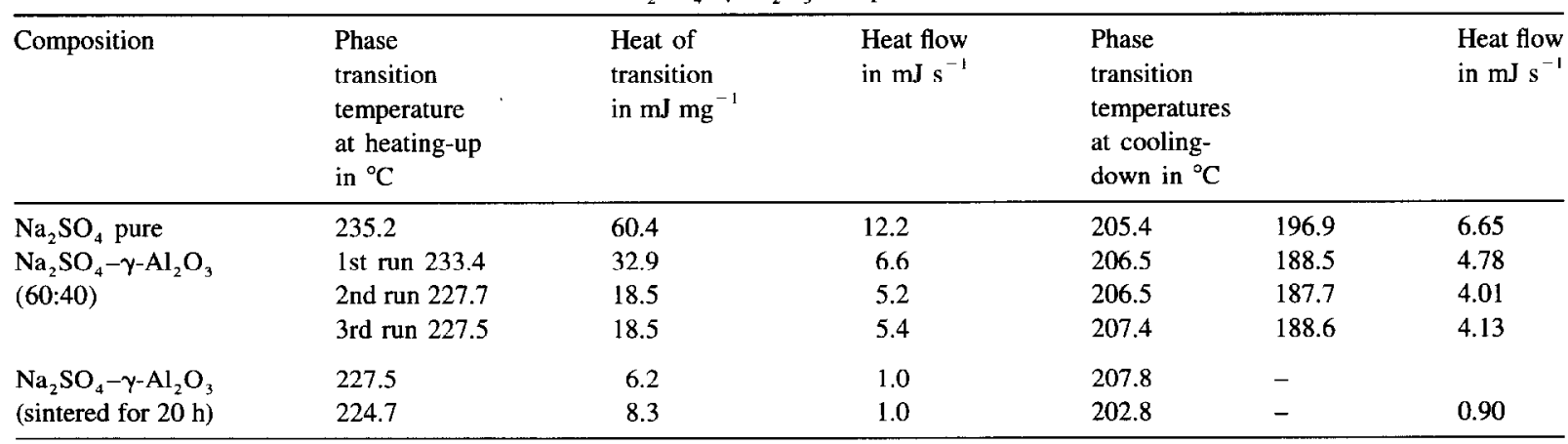


effects could be observed accompanied by an enhancement in conductivity:

(i) Homogeneous doping depending on solubility.

(ii) Homogeneous and heterogeneous (mixed) doping. This effect can be accompanied by the formation of a compound.

(iii) Heterogeneous doping with $\gamma-\mathrm{Al}_{2} \mathrm{O}_{3}$. This effect occurs in systems of (ii)-type as well.

Besides the enhancement in electrical conductivity, mixed and heterogeneous doping leads to both a better sinterability and, therefore, mechanical strength and an improved thermal shock resistance. The temperature of phase transition shifts towards lower values from higher to lower temperatures and the kinetic rate of transition becomes very slow as observed with the $\mathrm{Na}_{2} \mathrm{SO}_{4}$ (III) $\rightarrow \mathrm{Na}_{2} \mathrm{SO}_{4}$ (I) system.

\section{Acknowledgements}

The authors wish to thank F. Barwisch. P. Schmidt, A. Simmich, B. Löscher, H. Wulff, H.-H. Möbius, P.J. Gellings and E. Nadler.

\section{References}

[1] M. Gauthier, A. Chamberland, J. Electrochem. Soc. 124 (1977) 1579

[2] C.C. Liang, J. Electrochem Soc. 120 (1979) 1289.

[3] U. Guth, F. Barwisch, H. Wulff, P. Schmidt, H.-H. Mobius, Cryst. Res. Technol. 22 (1987) 141.

[4] U. Guth, S. Brosda, B. Löscher, A. Simmich, P. Schmidt, H.-H. Möbius, Mater. Sci. Forum 76 (1991) 137.

[5] K. Singh, S.S. Bhoga, Solid State Ionics 39 (1990) 205.

[6] H.-D. Wiemhöfer, S. Brosda, H. Keller, U. Guth, W. Gröpel, Proc. Int. Symposium on Environmental Sensing '92, 22-26 June 1992, Berlin.

[7] U. Guth, P. Schmidt, R. Jahn, S. Brosda, H.-H. Möbius, Solid State Ionics 36 (1989) 127.

[8] J.B. Wagner Jr., Composite solid electrolyte conductors, in: T. Takahashi (Eds.), High Conductivity Solid Ionic Conductors, Singapore, 1989, p. 146.

[9] A. Lunden, Solid State Ionics 28-30 (1988) 163.

[10] E.A. Secco, Solid State Ionics 28-30 (1988) 168.

[11] U. Guth, F. Barwisch, K. Elsner, J. Rosenkranz, P. Schmidt, H.-H. Möbius, Ionentransportprozesse in Festkörpern, Universität Jena, 1986, p. 176.

[12] R.M. Murray, E.A. Secco, Can. J. Chem. 56 (1978) 2616. 